\title{
平滑回路なし電圧形インバー夕駆動誘導電動機の 解析法と基礎特性
}

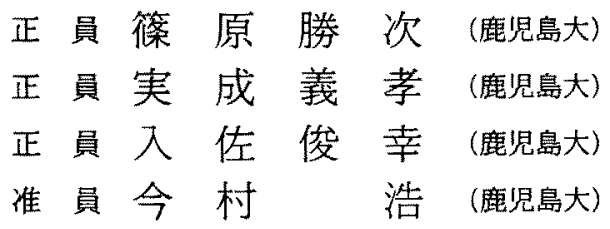

\section{1、まえがき}

GTO, BIMOS, パワーMOSFET, IGBTなどの 自己消弧形半導体スイッチング素子およびマイクロコ ンピュータの性能の向上により電動機駆動用 PWM インバータの研究が盛んに行われている。これらの高 周波デバイスとディジタル技術により，電圧形・電流 形インバータとも, 正弦波入出力化, 無馶音化などが 実現されている(1)。しかし，これらのインバータに㭁 いては，直流りンク部に平滑回路を有している。すな わち, 電圧形インバータでは電解コンデンサとリアタ トル（生は抵抗）を, 電流形インバータでは直流り アクトルを使用しているため, 装置の小形化, コンパ ーターインバータ間の高速応答性の障害となっている。

電圧形インバータに使用されれている電解コンデンサ はインバータ内の他の構成部品より寿命が短く, 信頼 性も少し劣るのが現状である。また，装置内でのスぺ ースもかなりの割合を占めている。

高橋らは電解コンデンサの容量を大幅に隇らし, こ のために生ずる電源リフルルよる電圧ベクトルの大き さの変動を補供する回路方式について報告してい $\zeta^{(2) \sim(4)}$ 。

この方式は従来の平滑回路有りの $1 / 100$ 程度のコン テンサ容量で済むので，電解コンデンサである必要が

Analysis and Fundamental Characteristics of Induction Motor Driven by Voltage Source Inverter without DC Link Compo. nents. By Katsuji Shinohara, Member, Yoshitaka Minari, Mem. ber, Toshiynki Irisa. Member \& Yutaka Imamura. Associate (Faculty of Engineering. Kagoshima University).

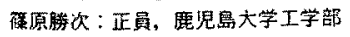

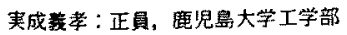

入传俊幸：正負，鹿照煘大学工学部

今村 浩: 准貣, 鹿思息大学工学部

電学論D，109卷 9 号，平成元年
ない特長を有する。これに対して本方式は，ほほ同じ 容量のコンデンサ 3 個を交流フィルタ部に必要とし若 干複雑になるが，コンバータの入力端に接続できる。 また本方式では，誘導機の漏れインダクタンスに蓄え られるエネルギーを交流電源に帰還するため、コンバ 一夕部をインバータ部と同じような構成にする必要が あるので，四象限運転用の回路に適する。Ziogasら は, 平滑回路なし電圧形インバータについて，その回 路方式, PWM スイッチンダパターン決定上の留意点 について述へているが，その対象は $R-L$ 静止負荷で ある(5)。

著者らは、これまで平滑回路をなくした新しい誘導 電動機駆動用電圧形インバータの回路方式を提案し, 方形波および PWM 波形で駆動した場合の運転特性， 解析結果などについて報告してきた ${ }^{(6) \sim 99} 。$

本論文では，まず平滑回路なし電圧形インバータの 構成放よびその基本動作を説明した。次に，電圧べク トルに対応する回路方程式から交流フィルタも含めた 詳細な解析を状態変数法を利用して求めた。この数值 計算結果より各部の瞬時波形および滑りに対する誘道 電動機のトルクー一次電流特性などを明らかにした。 最後に,これらの計算結果が実験結果と良く一致する ことを示した。

\section{2. 回路搆成と回路動作}

〈2・1〉回路構成図 1 に平滑回路なし電圧形イ ンパータの回路図を示す。主回路はインバータ,コン バー夕捛よび交流フィルタから構成されている。イン バータ部はパワーMOSFET モジュールを使用し, コンバータ部はダイオードと GTOの逆亚列で構成し ている。インバータは同期式の正弦波変調であり、搬 送波 $\left(f_{0}\right)$ の信号波 $\left(f_{s}\right)$ に対する周波数比 $N$ は $f_{s}=30$ 


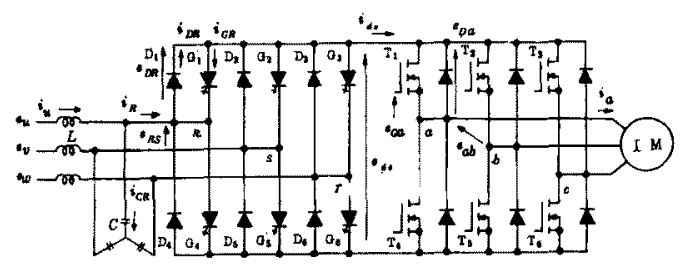

図 1 インバー夕回路

Fig. 1. Inverter circuit.

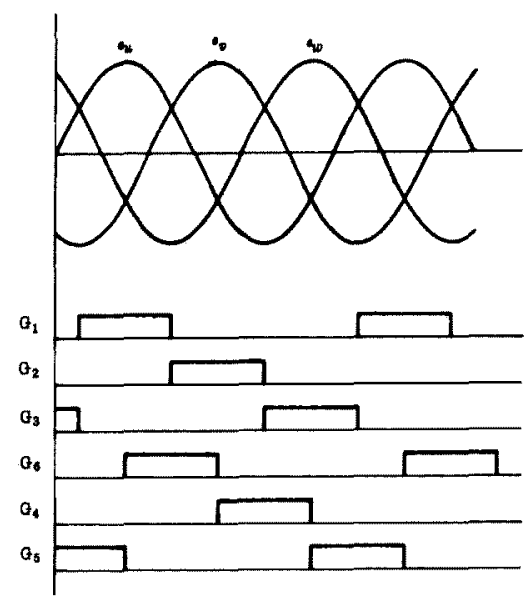

图 2 GTO ゲート信号波形

Fig.2. Gate signals of GTO.

$\mathrm{Hz}$ で $33, f_{s}=60 \mathrm{~Hz}$ で 15 とした。コンパータ部の GTOのゲートには, それと並列に接続されているダ イオードが導通する $120^{\circ}$ の期間だけオン信号を常時 印加している。

図 2 に電源の相電圧と GTOのゲート信号の関係を 示す。交流フィルタ部 $L C$ はインバータ扔よび GTO スイッチング時に, 直流リンク部邨よび交流電源ライ ンに発生する過電圧の吸収と, 交流電源電流波形の改 善のために挿入する。また，Cの作用により交流電源 からみた変換器全体の力率も良くなる。

〈2・2〉回路動作 図 3 に基本動作波形を示す。 同図はインバータ周波数 $f_{B}=60 \mathrm{~Hz}$, 搬送波の周波数 $f_{0}=900 \mathrm{~Hz}$, 変調率 $0.795 て 00.75 \mathrm{~kW}$ 誘導電動機を 無負荷運軽したときの波形である。これは電気角で $60^{\circ}$ の範囲の波形である。この区間で，電圧べクトル は $V_{0}, V_{1}, V_{5}, V_{6}, V_{7}$ た゚けの五種類である。また，回 路動作としては $i_{d c}$ の波形からわかるように流入・㷌 還・環流動作の三種類のみである。なぜなら、コンバ 一夕出力電圧 $e_{d c}$ は正であるので，コンバー夕出力電 流 $i_{d c}$ の正, 負, 零がそれそれ流入, 㷌摆, 環流に相

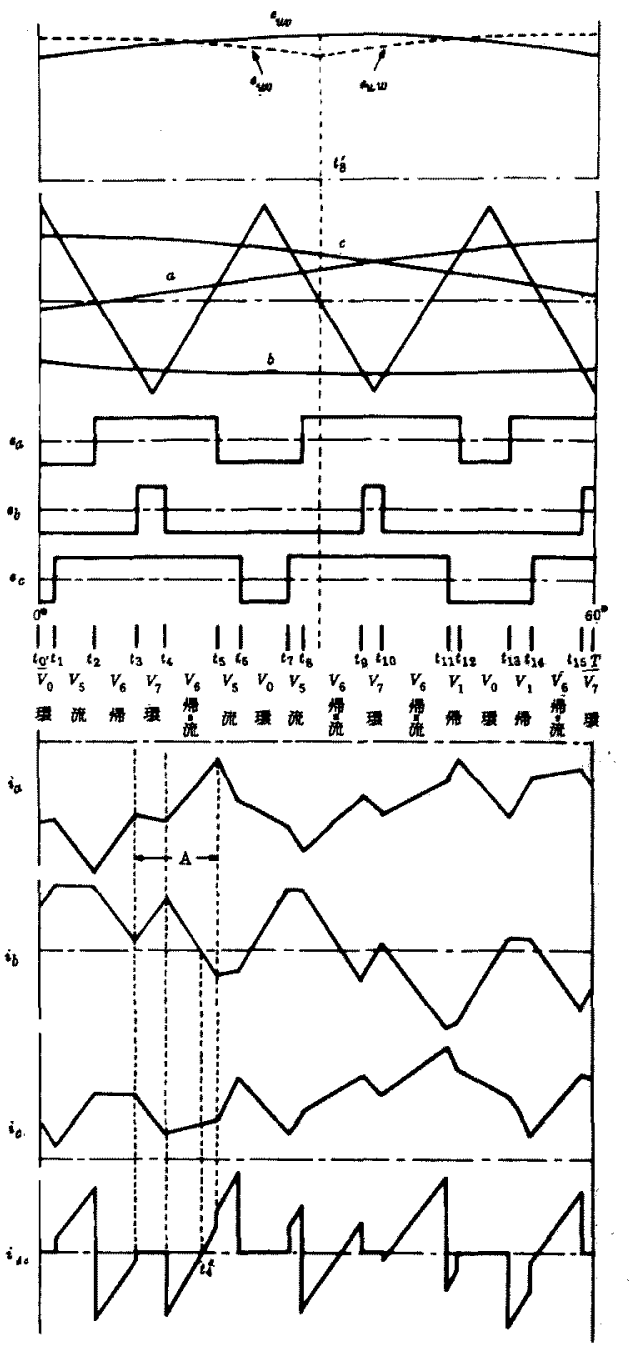

図 3 基本動作波形 $(N=15, M=0.795)$

Fig.3. Basic operation waveforms $(N=15, M$ $=0.795$ ).

当する。図 3 で $V_{0}, V_{7}$ は環流動作のみ， $V_{1}$ も㷌罢動 作のみ， $V_{5}$ と $V_{6}$ は流入と帰還のいずれか，または両 方の動作が存在する。

図 3 て $A$ 部分に相当する回路動作を図 4 に示す。 (a)図では，コンバータ部とインパー夕部の相互干涉 はなく，インバー夕部は環流動作を行っている。(b) 図ては破線の帰還動作と一点鎖線の環流動作の雨方が 存在するが，回路全体としては帰還動作である。(c) 図では実線の流入動作と一点鎖線の環流動作の両方が 存在するが，全体としては流入動作である。 

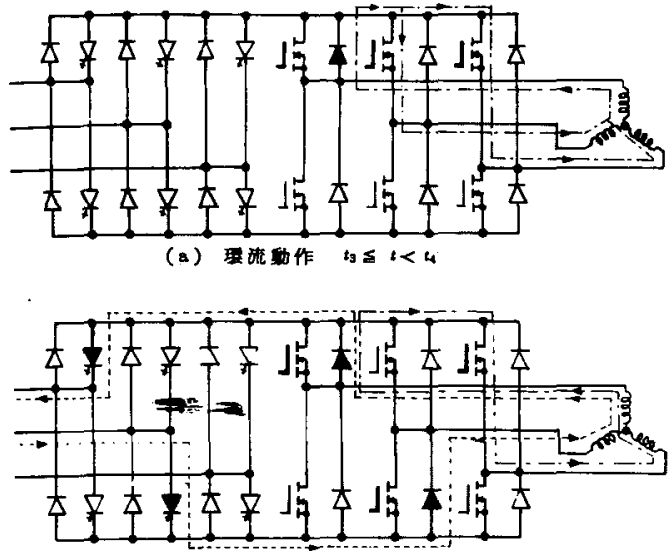

(b) 为通的作 $4 \leq t<4^{\prime}$

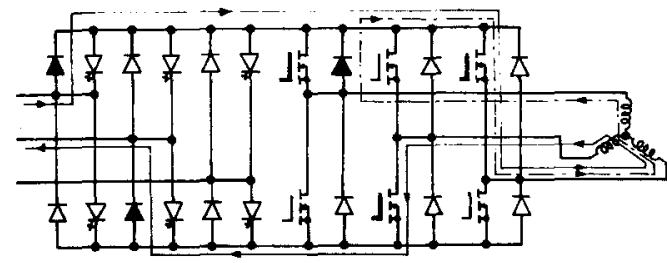

(c) 硫入为作 $w^{\prime} \leq<t_{5}$

図 4 回路動作

Fig.4. Circuit operations.

\section{3. 解析方法およひ数值計算結果}

解析を簡単にするため, 誘導電動機に印加される電 圧波形は相間対称で，かつ各相とも正負対称であると 仮定する。これを満足するため，搬送波の信号波に対 する倍率 $N$ は 3 の倍数で奇数とする。

〈3・1〉等価回路 等価回路は図 4 の環流・帰還・ 流入動作に関係なく，インバータのゲート信号によっ て決まる電圧べクトルで一義的に表される。例えば, 図 4 (b)，（c ）は㷌還・流入動作に対応しているが, コンバータ,インバータ, 誘導電動機相互の接続状態 は同じである（電圧べクトル $V_{6}$ として表される）。 図 5 に $V_{6}, V_{5}, V_{0}\left(V_{7}\right)$ および $V_{1}$ モードでの等価回路 を示す。

いま図 5 の等価回路において, 各モ一ド共通に

$$
\begin{aligned}
& i_{u}+i_{v}+i_{w}=0 \\
& e_{u v}-L \frac{d}{d t} i_{u}+L \frac{d}{d t} i_{v}=e_{C R}-e_{C S} \cdots \cdots \cdots \\
& e_{v w}-L \frac{d}{d t} i_{v}-L \frac{d}{d t}\left(i_{u}+i_{v}\right)=e_{C S}-e_{c T} \\
& e_{C R}+e_{C S}+e_{C T}=0
\end{aligned}
$$

であり， $V_{5}$ モードにおいて以下の関係式が成立する。
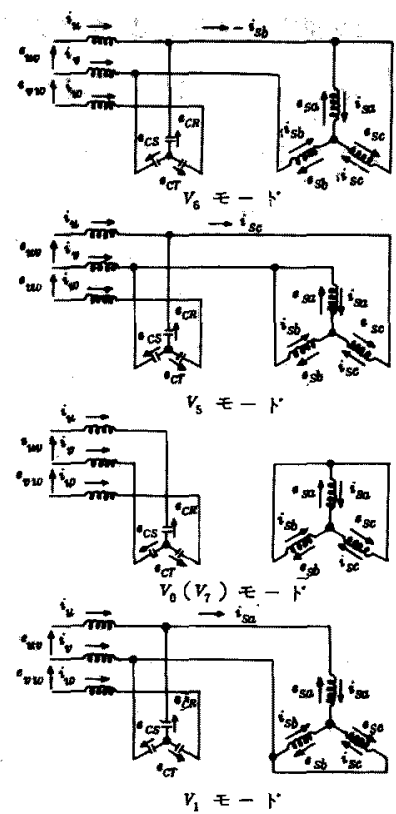

図 5 各モードにおける等価回路

Fig.5. Equivalent circuits of each mode

$$
\begin{aligned}
V_{6} \text { モード } & \\
e_{c R} & =e_{c s}=e_{s a}-e_{s b} \cdot \\
e_{s a} & =e_{s c} \quad \cdots \ldots \ldots \ldots . . . \cdots \\
e_{c R} & =\frac{1}{c} \int\left(i_{u}+i_{s b}\right) d t \\
e_{c s} & =\frac{1}{c} \int\left(i_{v}-i_{s b}\right) d t
\end{aligned}
$$

$V_{5}$ モード方程式は付録 1 に示す。 $e_{s a}, e_{s b}, e_{s c}$ を(9) 式で $e_{s \alpha}, e_{s \beta}$ に静止座標変換する。

$$
\left[\begin{array}{l}
e_{s a} \\
e_{s \beta}
\end{array}\right]=\sqrt{\frac{2}{3}}\left[\begin{array}{ccc}
\sqrt{3} / 2 & 0 & -\sqrt{3} / 2 \\
-1 / 2 & 1 & -1 / 2
\end{array}\right]\left[\begin{array}{l}
e_{s a} \\
e_{s b} \\
e_{s c}
\end{array}\right]
$$
$i_{s a}, i_{s b}, i_{s c}$ の $i_{s a}, i_{s \beta}$ への変換も(9)式を使用する。 誘導電動機の電圧, 電流方程式は, 静止座標変換した 量を更に瞬時値対称座標変換することにより(10)式と なる(11)。

$$
\left[\begin{array}{l}
\boldsymbol{e}_{s} \\
\mathbf{0}
\end{array}\right]=\left[\begin{array}{cc}
r_{s}+L_{s} p & M p \\
M\left(P-j P \omega_{r}\right) & r_{r}+L_{r}\left(p-j P \omega_{r}\right)
\end{array}\right]\left[\begin{array}{l}
i_{s} \\
i_{r}
\end{array}\right]
$$

ただし，

$$
\begin{aligned}
& e_{s}=\frac{1}{\sqrt{2}}\left(e_{s \alpha}+e_{s \beta}\right) \quad i_{s}=\frac{1}{\sqrt{2}}\left(i_{s a}+i_{s \beta}\right) \\
& i_{r}=\frac{1}{\sqrt{2}}\left(i_{r a}+i_{r \beta}\right)
\end{aligned}
$$


ここで,二次鎖交磁束ペクトル $\boldsymbol{\phi}_{r}$ を次式で導入する。

$$
\boldsymbol{\phi}_{r}=\frac{1}{\sqrt{2}}\left(\phi_{r a}+j \psi_{r \beta}\right)=\boldsymbol{M} \boldsymbol{i}_{s}+L_{r} \boldsymbol{i}_{r}
$$

(10)式の $\boldsymbol{i}_{\tau}$ の部分に(11)の式を代入すると，次式と なる。

$$
\left[\begin{array}{c}
\boldsymbol{e}_{s} \\
0
\end{array}\right]=\left[\begin{array}{cc}
r_{s}+\sigma L_{s} p M p / L_{r} \\
-\sigma_{r} M & p-\boldsymbol{a}_{r}
\end{array}\right]\left[\begin{array}{l}
\boldsymbol{i}_{s} \\
\boldsymbol{\psi}_{r}
\end{array}\right]
$$

$$
\text { ただし, }
$$

$$
\begin{aligned}
& \sigma=1-M^{2} / L_{s} L_{r} \quad \sigma_{r}=r_{r} / L_{r} \\
& a_{r}=\sigma_{r}+j P \omega_{r}
\end{aligned}
$$

〈3.2〉俰数行列およひ接続行列 $V_{6}$ モードでの 保数行列 $A_{6}$ を次に求める。電源の相電圧の大きさを $V_{m}$ ，角速度を $\omega_{s}$ とすると，

$$
\left.\begin{array}{l}
e_{u}=V_{m} \sin \omega_{s} t \\
e_{v}=V_{m} \sin \left(\omega_{s t}-2 \pi / 3\right) \\
e_{\omega}=V_{m} \sin \left(\omega_{s} t-4 \pi / 3\right)
\end{array}\right\}
$$

であり，これらは仮想の二相電圧

$$
\left.\begin{array}{l}
e_{1}=V_{m} \sin \omega_{s} t \\
e_{2}=V_{m} \cos \omega_{s} t
\end{array}\right\}
$$

の組合せで表せるので，線間電圧 $e_{u v}$ は次式となる。

$$
\begin{aligned}
& e_{u v}=\frac{3}{2} e_{1}+\frac{\sqrt{3}}{2} e_{2} \\
& e_{v w}=-\sqrt{3} e_{2}
\end{aligned}
$$

(1) (8)式に扔いて末知数は $e_{v v}, e_{v w}, i_{u}, i_{v}, i_{w}$, $e_{C R}, e_{c s}, e_{c T}, e_{s a}, e_{s b}, e_{s c}, i_{s a}, i_{s b}, i_{s c}$ の計 14 個である。 (9)式で $e_{s a}, e_{s b}, e_{s c}$ を $e_{s a}$ と $e_{s \beta} に\left(i_{s a}, i_{s b}, i_{s c}\right.$ に関 しても同様）変換し， $e_{u v}, e_{v w}$ を(14)式の $e_{1}, e_{2}$ で表 わすと, 未知数注 $e_{1}, e_{2}, i_{t w}, i_{v}, i_{w}, e_{C R}, e_{c s}, e_{c T}, e_{s a}$, $e_{s \beta}$, の計 12 個となる。(1)〜 (8)，(12)式括よび (14)式を利用することにより, 前記 12 個の末知数に $\psi_{r a}, \psi_{r \beta}$ 老加えた 14 個の末知数に関して，次の(15) 〜(19)式が得られる。

$$
p x=A_{6} x
$$
ただし，

$$
x=\left[e_{1}, e_{2}, i_{u}, i_{v}, e_{c R}, e_{c s}, i_{s a}, i_{s \beta}, \psi_{r a}, \psi_{r \beta}\right]^{T}
$$

$$
A_{6}=\left[\begin{array}{cccccc}
0 & \omega_{s} & 0 & 0 & 0 & 0 \\
-\omega_{s} & 0 & 0 & 0 & 0 & 0 \\
1 / L & 0 & 0 & 0 & -1 / L & 0 \\
-1 / 2 L & -\sqrt{3} / 2 L & 0 & 0 & 0 & -1 / L \\
0 & 0 & 1 / C & 0 & 0 & 0 \\
0 & 0 & 0 & 1 / C & 0 & 0 \\
0 & 0 & 0 & 0 & 0 & 0 \\
0 & 0 & 0 & 0 & -K_{5} & K_{5} \\
0 & 0 & 0 & 0 & 0 & 0 \\
0 & 0 & 0 & 0 & 0 & 0
\end{array} \boldsymbol{A}_{62}\right.
$$

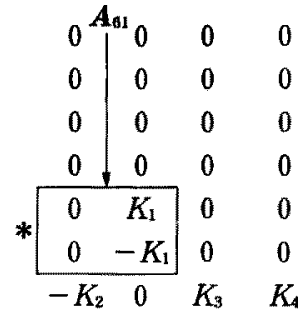

$$
\begin{aligned}
& \begin{array}{llll}
0 & -K_{z}-K_{4} & K_{3}
\end{array} \\
& \begin{array}{llll}
K_{6} & 0 & -\sigma_{r}-P \omega_{r}
\end{array} \\
& \begin{array}{llll}
0 & K_{b} & P \omega_{r} & -\sigma_{r}
\end{array}
\end{aligned}
$$$$
\text { ここで, }
$$

$$
\begin{aligned}
& r_{s e}=r_{s}+(1-\sigma) L_{s} L_{r}, K_{1}=\sqrt{2} / \sqrt{3} C, \\
& K_{2}=r_{s e} / \sigma L_{s} \\
& K_{3}=\sigma_{r} M / \sigma L_{s} L_{r}, K_{4}=P \omega_{r} M / \sigma L_{s} L_{r} \\
& K_{5}=\sqrt{2} / \sqrt{3} \sigma L_{s}, K_{6}=\sigma_{r} M \\
& i_{\omega}=-i_{u}-i_{v} \\
& e_{C T}=-e_{C R}-e_{C S} \\
& e_{s \alpha}=\left(r_{s e}+\sigma L_{s} p\right) i_{s a}+M \operatorname{Re}\left(a_{r} \cdot \boldsymbol{\psi}_{r}\right) / L_{\tau}
\end{aligned}
$$

$$
e_{s \beta}=\left(r_{s e}+\sigma L_{s} p\right) i_{s \beta}+M \operatorname{Im}\left(\boldsymbol{a}_{\tau} \cdot \boldsymbol{\psi}_{r}\right) / L_{r}
$$

（16）式の実線で囲まれた小行列を $A_{61}$, 破線で曲まれ た小行列を $A_{62}$ とする。 $V_{5}, V_{0}, V_{1}$ モードでの保数行 列は, この小行列 $A_{61}, A_{62}$ に相当する部分だけが $A_{6}$ から異なり $A_{51}, A_{52}$ などとなる。

また，瞬時トルクてに関しては次式が成立する。

$$
\tau=P M \operatorname{Im}\left(\boldsymbol{i}_{s} \boldsymbol{\psi}_{r}^{*}\right) / L_{r}
$$

$$
\text { ここで,* : 複素共役 }
$$

ここでは，60度期間のみを考えているので，(22)式 で表される接続行列 $\boldsymbol{B}_{c}$ を導入することにより(23) 式 が成立する。

$$
\begin{aligned}
& \boldsymbol{B}_{c}=\left[\begin{array}{ccccc}
\boldsymbol{B}_{c 1} & \mathbf{0} & \mathbf{0} & \mathbf{0} & \mathbf{0} \\
\mathbf{0} & \boldsymbol{B}_{c 2} & \mathbf{0} & \mathbf{0} & \mathbf{0} \\
\mathbf{0} & \mathbf{0} & \boldsymbol{B}_{c 2} & \mathbf{0} & \mathbf{0} \\
\mathbf{0} & \mathbf{0} & \mathbf{0} & \boldsymbol{B}_{c 3} & \mathbf{0} \\
\mathbf{0} & \mathbf{0} & \mathbf{0} & \mathbf{0} & \boldsymbol{B}_{c 3}
\end{array}\right] \ldots \ldots \ldots \ldots \\
& \text { ここで, } \\
& \boldsymbol{B}_{\mathrm{c} 1}=\left[\begin{array}{cc}
1 / 2 & -\sqrt{3} / 2 \\
\sqrt{3} / 2 & 1 / 2
\end{array}\right], \quad \boldsymbol{B}_{c 2}=\left[\begin{array}{cc}
1 & 1 \\
-1 & 0
\end{array}\right], \\
& \boldsymbol{B}_{c 3}=\left[\begin{array}{cc}
1 / 2 & \sqrt{3} / 2 \\
-\sqrt{3} / 2 & 1 / 2
\end{array}\right] \\
& \boldsymbol{x}\left(O_{+}\right)=\boldsymbol{B}_{\mathrm{a}} \boldsymbol{x}\left(T_{-}\right)
\end{aligned}
$$

〈3*3〉状態方程式の解法图5の各区間で次式 が成り立つ。 


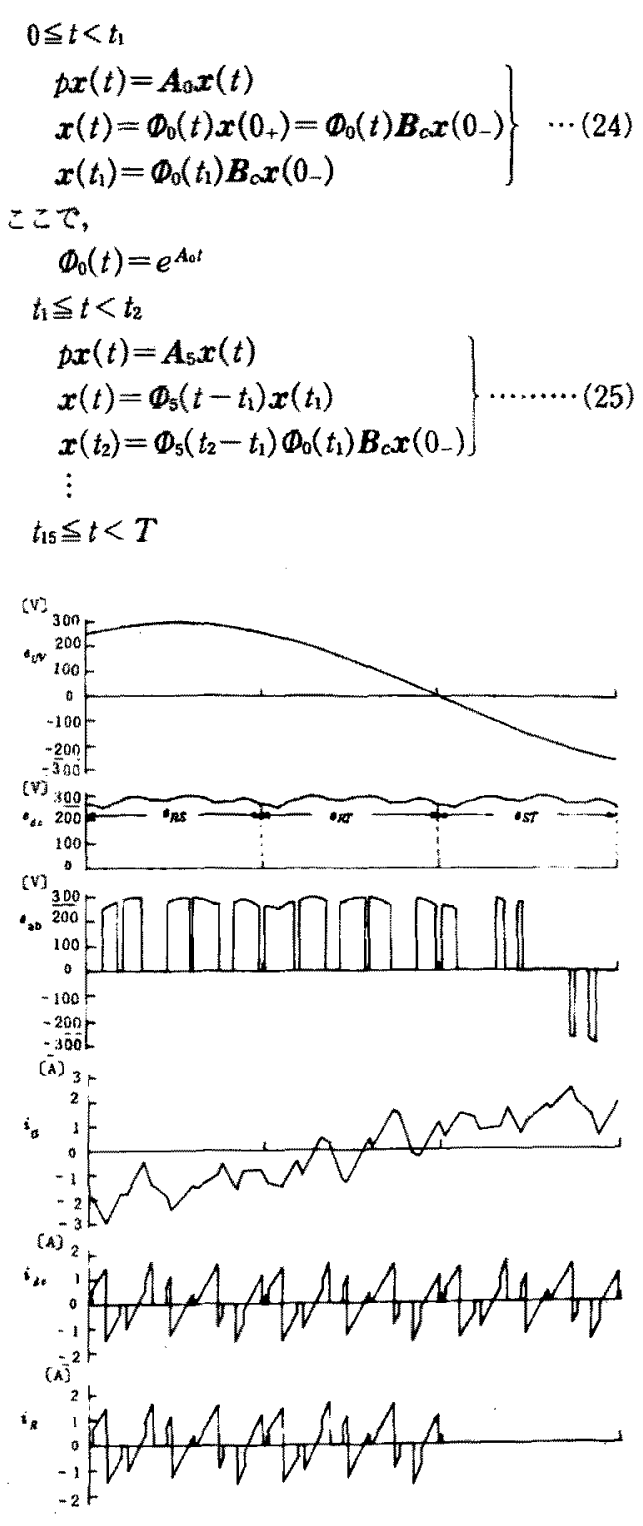

$$
\begin{aligned}
x(t)= & \Phi_{0}\left(t-t_{15}\right) \boldsymbol{x}\left(t_{15}\right) \\
\boldsymbol{x}\left(T_{-}\right)= & \Phi_{0}\left(T-t_{15}\right) \Phi_{1}\left(t_{15}\right. \\
& \left.-t_{14}\right) \cdots \Phi_{0}\left(t_{1}\right) \boldsymbol{B}_{c} x\left(0_{-}\right) \\
& \equiv \boldsymbol{H} \boldsymbol{x}\left(0_{-}\right) \cdots \cdots \cdots \cdots \cdots \cdots
\end{aligned}
$$

周期性の条件より

$$
\boldsymbol{x}\left(T_{-}\right)=\boldsymbol{x}\left(0_{-}\right)
$$

であるのて，次式が成立する。

$$
(H-I) x\left(0_{-}\right)=0
$$

10 元連立方程式である(28)式をがウスの消去法て解 き $\boldsymbol{x}\left(0_{-}\right)$を求めた。

ここで検討しているインバータ部の $60^{\circ}$ 区間で，コ ンバータ部のダイオード間の転流が存在する場合（図 $3 て ゙ e_{u v}, e_{u w}$ が破線に相当) の係数行列㧍よび状態方 程式の解法については省略する。

〈3.4〉数值計算結果以下, 図 $6 \sim$ 図 9 では, $f_{s}=60 \mathrm{~Hz}, f_{0}=900 \mathrm{~Hz}, N=f_{0} / f_{s}=15, M=0.915, V=$ $200 \mathrm{~V}$ の条件で計算を行う。

表1の定数を使用した各部の計算波形を図 6 に示 す。上から, 電源電压 $e_{u v}$, 直流りンク部電圧 $e_{d c}$, 誘 導機線間電压 $e_{a b}$, 誘導機相電流 $i_{a}$, 直流りンク部電流 $i_{d t}$, コンバータ入力電流 $i_{R}$, 交流コンデンサ入力電流 $i_{C R}$, 交流電源からの入力電流 $i_{u}$ である。コンバータ の入力線間電珐波形 $e_{R 5}$ が交流フィルタの括入で電源 の線間電压波形 $e_{u v}$ よりわすかにひずんでいる。最初 $の \pi / 3$ の期間に枪いて, 誘導機線間電压のピーク值

表 1 誘導電動機极よびインパー夕定数 Table 1. Induction machine and inverter constants.

\begin{tabular}{r|r}
\hline$P_{\theta}=0.75 \mathrm{~kW}$ & $r_{+}=2.09 \mathrm{\Omega}$ \\
\hline$V=200 \mathrm{~V}$ & $L_{\mathrm{x}}=L,=0.192 \mathrm{H}$ \\
\hline$f=60 \mathrm{~Hz}$ & $M=0.184 \mathrm{H}$ \\
\hline$P=4$ & $C_{Y}=22.5 \mu \mathrm{F}$ \\
\hline$r_{\mathrm{N}}=3.45 \Omega$ & $L=4 \mathrm{mH}$ \\
\hline
\end{tabular}
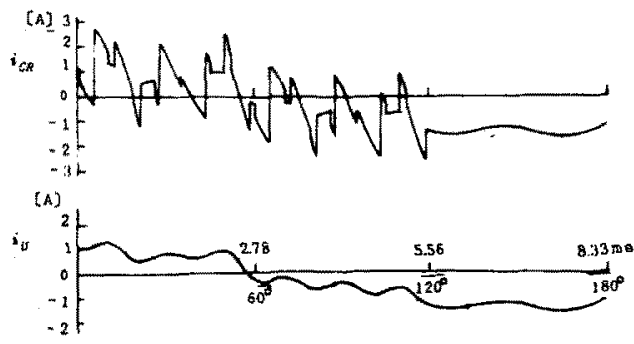

図 6 各部の計算波形 $(s=0.056 \%)$

Fig.6. Calculated waveforms in various parts $(s=0.056 \%)$.

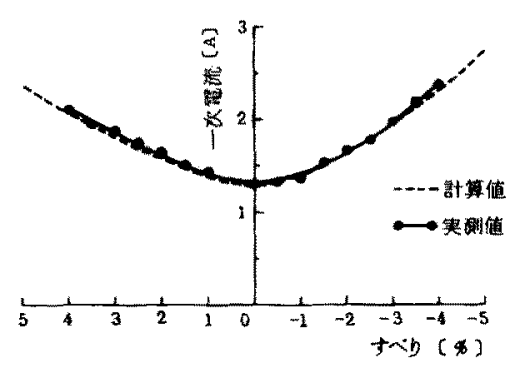

图 7 一次電流特性

Fig.7. Stator current characteristics. 


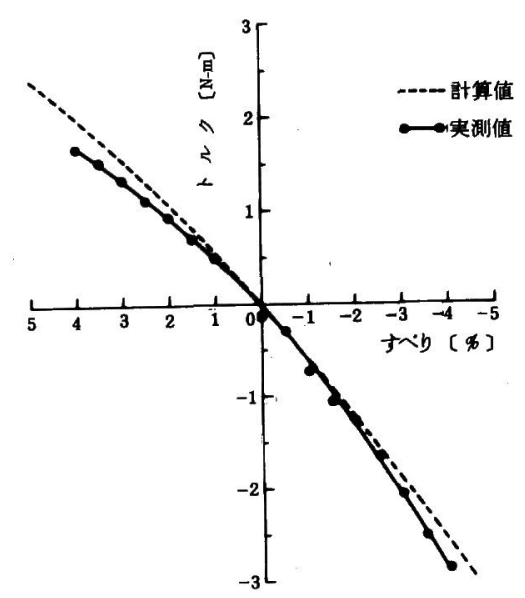

図 8 出力トルク特性

Fig.8. Output torque characteristics

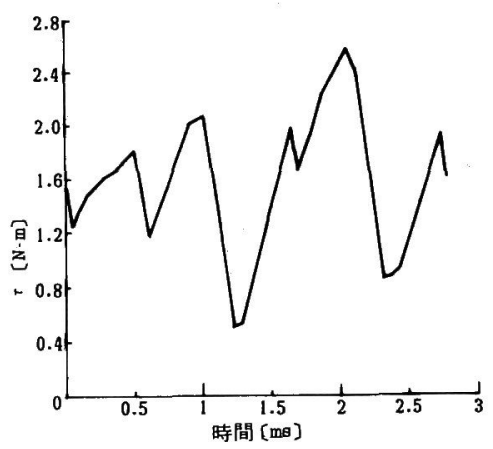

図 9 瞬時トルク波形

Fig.9. Calculated waveform of instantaneous torque $(s=3 \%)$.

の包絡線は，この $e_{R S}$ の波形に等しい。直流リンク部 電流 $i_{d c}$ が正, 負, 零に変化していることがわかる。 交流フィルタ部のコンデンサ電流 $i_{C R}$ はコンバータ入 力電流 $i_{R}$ のパルス分を吸収しているので, 交流電源 からの入力電流 $i_{u}$ はほほ正弦波になっている。

図 7, 図 8 に滑りに対する一次電流および出カトル ク特性の計算值を破線でそれぞれ示す。

図 9 に滑り $s=3 \%$ の瞬時トルク波形の計算値を 示す。誘導機電流波形 $i_{a}$ の脈動のためのトルクに脈 動を生じている。

\section{4. 実験結果}

〈4・1〉各部の波形と出力特性 図 10 に図 6 の計 算波形に対応する各部の実測波形を示す。形状, 大き さともよく一致していることがわかる。

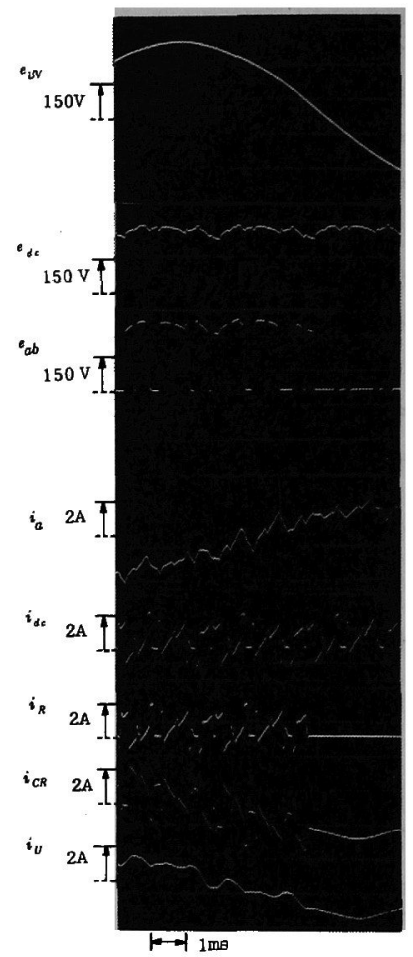

図 10 各部の実測波形 $(s=0.056 \%, N=$ $15, M=0.915, V=200 \mathrm{~V})$

Fig.10. Experimental waveforms in various parts $(s=0.056 \%, N=15, M=0.915, V=200$ V).

図 7 に誘導電動機の一次電流, 図 8 に出力トルクの 実測值を実線で示す。出力トルクの実測值は, 供試誘 導機に直流機を直結し, 力行領域では直流発電機とし ての入力, 回生領域では, 直流電動機としての出力を 直流機から求めた。すなわち, 軸トルクである。出力 トルクで，力行領域では計算值のほうが実測值より大 きく，回生領域ではその逆になっている。これは計算 で誘導機銅損のみを考慮し，鉄損などの損失を無視し ているためと思われる。

また, 一次電流, 出力トルクともに力行領域より回 生領域での值が大きい。これは正弦波での運転特性と 同じ傾向を示している。

〈4・2〉 交流フィルタの影響 交流フィルタ $L, C$ の大きさがコンバータ入力電流 $i_{R}$, コンデンサ入力電

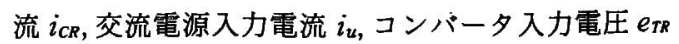
に及ほす影響を図 11 に示す。同図より,コンバータ 入力電流 $i_{R}$ の波形はフィル夕定数にはほとんど閔係 がないことがわかる。また, 交流フィル夕部の共振周 
波数 $f$ は次式で示される。

$$
f=\frac{1}{2 \pi \sqrt{L C}}
$$

$C=3 \mu \mathrm{F}, L=10 \mathrm{mH}$ では $f=919 \mathrm{~Hz}$ となり, インバ 一夕の PWM 周波数 $900 \mathrm{~Hz}$ に近いので $i_{C R}, i_{u}$ に大き

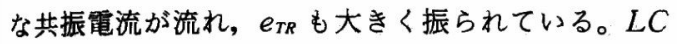
の積を増加すると, この PWM 周波数による共振は 避けられるが別の低次の脈動が $i_{u} に$ 生じている。図 1 のコンバータ入力電流 $i_{R}$ が近似的に 120 度通電の 電流源として働くので, この低次の脈動は $i_{R}$ の高調 波成分 $(6 n \pm 1, n=1,2,3)$ による $L C$ の共振で生じて いる。更に, LC の積を大きくすると $i_{u}$ は正弦波に

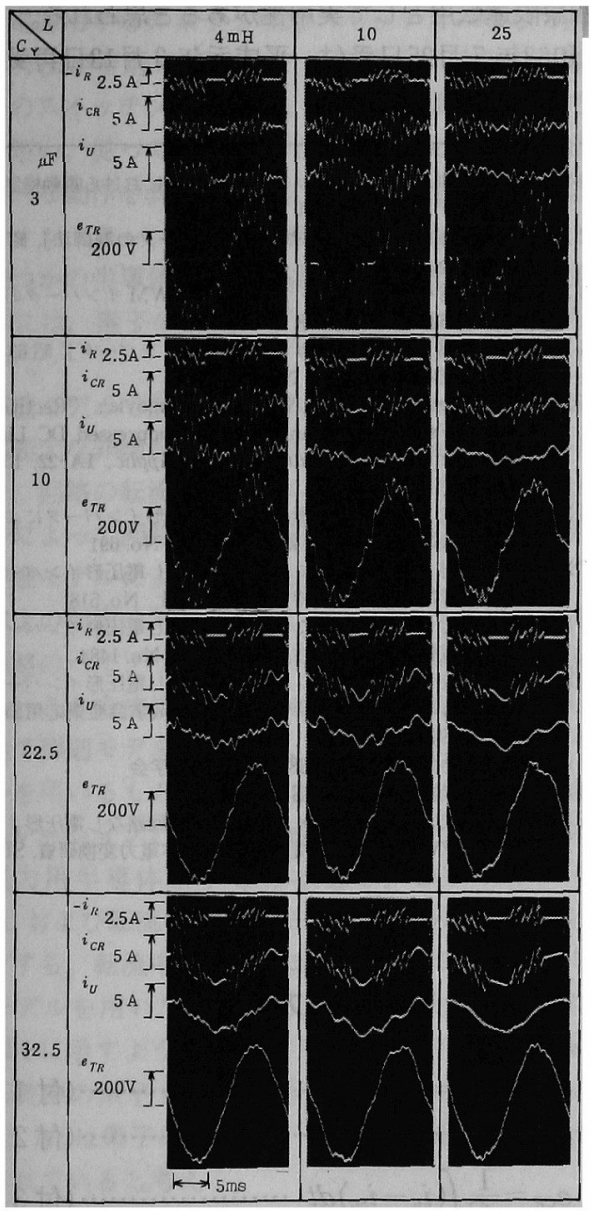

図 11 交流フィルタ変化時の電圧-電流波形 $(s=0.056 \%)$

Fig.11. Voltage and current waveforms with changing input capacitance and inductance ( $s=$ $0.056 \%$ )

電学論D, 109 巻 9 号, 平成元年
近くなるが，その振幅は大きくなる。

\section{5. 交流フィル夕定数の選定}

PWM 周波数 $f_{0}$ による交流フィルタの共振は, $f_{0}$ を高く設定することにより，LCの積の小さい所へ移 動するので, 以下 $f_{0}=4.5 \mathrm{kHz}$ で考える。更に, 直流

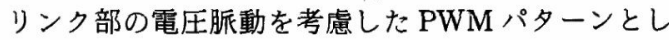
て，搬送波の振幅を電源電圧 $e_{u v}$ の三相全波で変謂し たものを考える ${ }^{(12)}$ (以下，搬送波変調と呼ぶ)。図 12 に $L=10 \mathrm{mH}$ での誘導機一次電流 $i_{a}$ および電源電流 $i_{u}$ のひずみ率を, 図 13 に交流フィルタ容量の計算值 を示す。比較のため, 従来の平滑電源でのひずみ率を 図 12 (a) に示す。 $i_{R}$ の高調波成分で $n \omega L=1 / n \omega C$ を

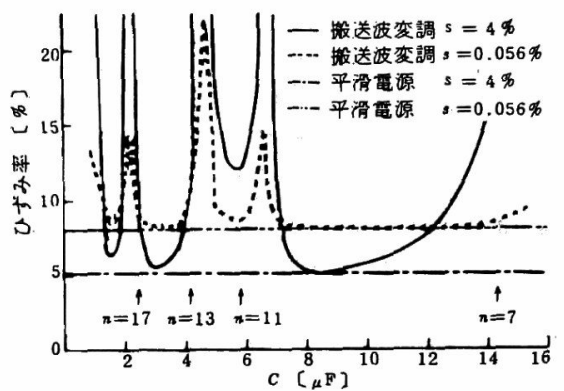

(a) $i_{a}$ のひずみ率

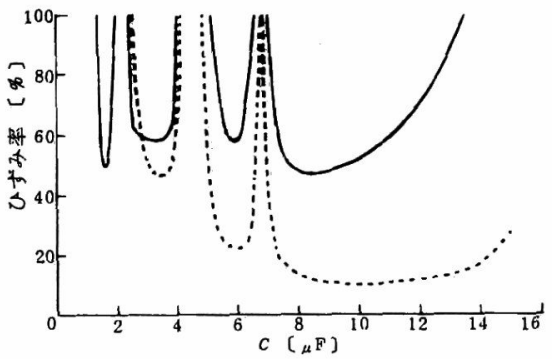

(b) i注のずみ率

図 $12 i_{a}, i_{u}$ のひずみ率特性 $(L=10 \mathrm{mH})$

Fig.12. Distortion factors of $i_{a}$ and $i_{u}(L=10$ $\mathrm{mH})$.

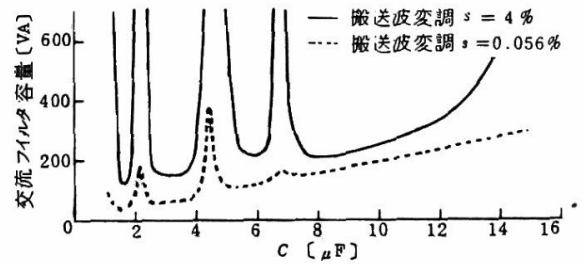

図 13 交流フィル夕容量特性 $(L=10 \mathrm{mH})$

Fig.13. Total kVA of input filter $(L=10 \mathrm{mH})$. 

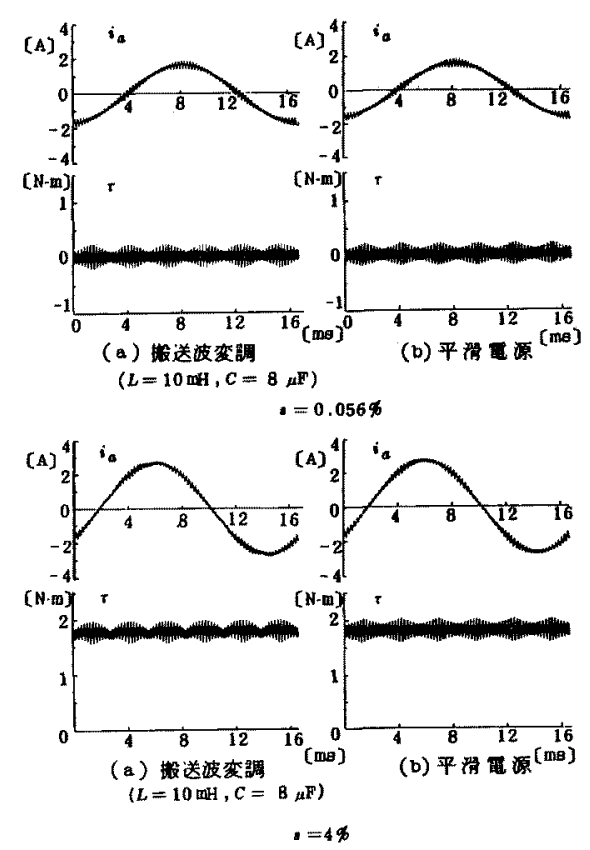

図 14 一次電流，卜ルクの計算波形 $(N=$ $75, M=0.795, V=200 \mathrm{~V})$

Fig.14. Calculated waveforms of stator cur. rent and torque $(N=7.5, M=0.795, V=200 \mathrm{~V})$.

満足するCの値を知印で示す。この共振周波数に相 当する $C$ の付近では $i_{a}, i_{u}$ のひずみ率が大きくなり， 交流フィル夕容量も增加する。ひずみ率および交流フ イル夕容量が小さくなる $L C$ の選択が望ましい。 $L=$ $10 \mathrm{mH}$ では $C=8 \mu \mathrm{F}$ の付近が適当であり，このとき の交流フィルタ容量は $s=4 \%$ ，204 VA（リアクト

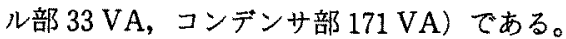

図 14 に平滑電源との運転特性の比較を示す。 $L=$ $10 \mathrm{mH}, C=8 \mu \mathrm{F}$ での運転ては， $i_{u}, \tau$ の波形とも， 平滑電源での波形とほとんど同じであることがわか る。

\section{6.あとがき}

誘導機駆動用として，直流りンク部に平滑回路を有 しないPWM 電圧形インバー夕の回路方式の提案を 行った。次に，この回路で誘導機を運転した場合の解 析を行い，更に実験結果との比較より，次のことが明 らかになった。

（1）平滑回路なし電圧形インバータは電解コンデ ンサ,リアクトルなどの平滑回路部がないので信頼
性, 寿命の点で優れてお゙り，スペース的にも余裕がて き，小形化が可能である。

（2）しかしながら，直流りンク部の平滑回路を取 除いた代わりに，コンバータ部からのパルス状電流の 吸収・供給を行う交流フィルタが必要である。

（3）交流フィルタも考慮した平滑回路なし電圧形 インバータで誘導電動機を運転した場合の状態方程式 を導き，本回路方式の解析法を明らかにした。

（4）この解析法より各部の波形，誘導電動機の出 力特性を求め，それらを実験結果と比較し，良い一致 が得られることを確認した。

以上より，本インバータは電動機電流が直流りンク 部電圧の脈動の影響を受ける欠点はあるが，高信頼性 の四象限運転用として実用性があると思われる。 (昭和63年 7 月 25 日受付, 平成元年 3 月 13 日再受付)

\section{文 献}

（1）常広・松井：「パワーエレクトロニクスにおける数動機制御 技術」、電学論 D, 107, 1200 (昭 62-10)

（2）高棌・伊藤：「コンデンサレスインバータの制御法」，昭63 電気学会全大, No. 527

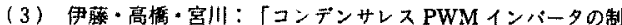
御法了。昭 63 同上, No. 528

(4) 伊藤・高嗬：「コンデンサレス PWM インバー夕」,昭 63 電 気学会磁㭉纫用部門全太, No. 95

(5) P.D. Ziogas, Y. Kang \& V.R. Stefanovic: "Rectifier Inverter Frequency Changers with Suppressed DC Link Components", IEEE Trans. Industr. Applic., IA-22. 1027 (1986)

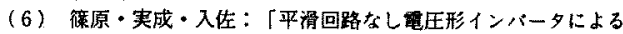

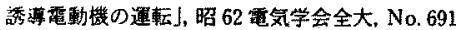

(7)：篗愿・今村・実成・入佐：f平滑回路なし进圧形インパータ

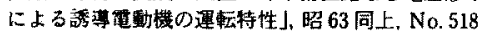

（8）筥原・今村・実成・入佐：「平滑回路なし雨圧形イン゙バー夕

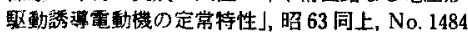

（9）策原・赛成・入传・今村：「平滑回路なし筆圧形インバータ

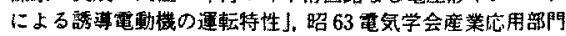
全大, No. 97

(10) - 半望体電力変换回路, p. 138 (昭 62) 電気学会

（11）基整電気機器学, p. 106 (昭 60)電岛学会

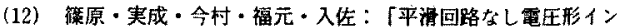

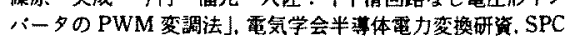
$-89-13$ (平元)

\section{付 . 録}

1.V泟モードにおける方程式

$V_{5}$ モード :

$$
\begin{aligned}
& \left.e_{C R}-e_{c s}=e_{s c}-e_{s a} \ldots \ldots \ldots \ldots \ldots \ldots \ldots \ldots \text { (付 } 1\right)
\end{aligned}
$$

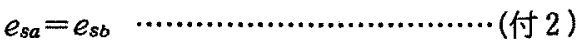

$$
\begin{aligned}
& e_{C R}=\frac{1}{C} \int\left(i_{u}-i_{s c}\right) d t \\
& e_{c s}=\frac{1}{C} \int\left(i_{v}+i_{s c}\right) d t
\end{aligned}
$$

